\title{
E-Learning Evaluation Process on the Faculty of Social and Political Sciences, Universitas Diponegoro
}

\author{
Sri Widowati Heriningsih ${ }^{1}$, Sri Suryoko ${ }^{2}$, Dyah Hariani ${ }^{3}$, Shary Charlotte ${ }^{4}$ \\ \{herieningsih@gmail.com ${ }^{1}$ \} \\ Universitas Diponegoro, Indonesia ${ }^{1,2,3,4}$
}

\begin{abstract}
The global pandemic of Covid-19 has an influential impact on university education, including students' learning process in Universitas Diponegoro. The presence of this corona virus outbreak hinders teaching and learning activities, which is usually carried out in a direct meeting. Previous researches of E-learning on higher education level showed that an effective online teaching and learning process must have a supportive organizational environment, a clarity of information, and a good service system. This has encouraged the Faculty Quality Assurance Team (Tim Penjaminan Mutu Fakultas/TPMF) of FISIP Undip to evaluate and measure the effectiveness of E-learning methods in this faculty. This descriptive quantitative research uses the ongoing evaluation research design, with primary data collected through online surveys from 636 Bachelor, Magister, and PhD students from five departments. The data are analyzed with Agustino's theory of evaluation indicators: (1) Human Resources; (2) Institutional; (3) Technology Facilities and Infrastructure; and (4) Financial. The result of this research indicates that even though there are many obstacles related to technological facilities and infrastructure, E-Learning turned out to be well received by the academic community in FISIP Undip.
\end{abstract}

Keywords: E-Learning, FISIP, Undip, Policy Evaluation

\section{Introduction}

Education is the most important element in building human resources. The development of the education world has respectively experienced various phases. The use of sophisticated electronic devices in various activities changes more and more activities from conventional to modern, and the support of the development of digitalization (the internet) also causes enhanced changes. The world of education has also experienced this impact with the e-learning process method.

E-learning is an educational system which uses internet media and computer networks to support the learning process [1]. The use of e-learning is expected to be able to make users, who are teachers and students, freely access the learning process in the form of material and attendance more easily without having to meet face to face directly [2]. Changes from the use of e-learning are known to be a learning process that can be done anywhere and anytime, thus becoming a solution of time and place constraints in the learning process [3].

Since 2019, Undip has made efforts to meet the IAPS 4.0 standards by implementing Single Sign On or SSO, a system that allows all activities of the academic community to be integrated and recorded in an application. Initially, this system only allowed students to do attendances online via SIAP and made it easier for students to access Wi-Fi via SSO. The Online Lecture Application (Aplikasi Kuliah Online) or Kulon has also been formed and introduced to 
lecturers since 2016. Unfortunately, the online lecture method is not very popular because the lecturers still rely on face-to-face teaching methods.

However, with the global Covid-19 pandemic hitting Indonesia and the world, it has forced all lectures and learning processes at Diponegoro University to be carried out online. This is also an implementation of the education and culture ministry's decision to close schools and universities to stop the Covid-19 pandemic. According to Chancellor's Circular No. 23/UN.7.P/SE/2020, since March 2020, Undip has been holding online lectures through a number of applications and programs such as Microsoft Teams, WhatsApp, Zoom, Kulon Undip, etc.

The Faculty of Social and Political Sciences (FISIP) is also one of the implementers of Kulon's e-learning. FISIP, which has a vision for 2015-2019, namely "Faculty of Social and Political Sciences, Universitas Diponegoro in 2020 to become "A Research Faculty that is Excellent in the Field of Social and Political Sciences", makes the process of using Kulon a form of implementation efforts to achieve this vision. Kulon, which has been running for more than 3 (three) years and over time, has also experienced improvements and added features, making Kulon feel the need to be evaluated to see the results of using Kulon in supporting the teaching and learning process so far.

\section{Research Method}

\subsection{Research Design}

The design of this research is an ongoing evaluation, a research that is conducted while a program is still ongoing. This research is a quantitative descriptive research, which is a research conducted to determine the value of the independent variable by using quantitative methods, namely through distributing questionnaires [4]. This research is conducted to determine and identify the results of the policy along with the desired results and deviations through the assessment of lecturers and students on the implementation of the teaching and learning process through Kulon at FISIP, Universitas Diponegoro.

\subsection{Data Collection Technique}

The data source used is primary data by distributing questionnaires to 636 students across the UNDIP FISIP generation from five different departments, namely Public Administration, Government Science, Business Administration, Communication Studies, and International Relations, from undergraduate, postgraduate and doctoral programs.

The entire questionnaire will then be processed through three stages, namely Editing, Coding, and finally Tabulation, entering data in certain tables and arranging numbers as well as calculating them.

\subsection{Measurement Scale}

The measurement scale used in this research is an interval measurement scale using the Rating Scale. Rating Scale is a tool used to obtain data in the form of a list containing the characteristics of the behavior to be investigated which must be recorded in stages. The assessment given by the observer is based on spontaneous observation of the behavior of another 
person, which takes place in socializing and communicating with that person for a certain period of time. The element of assessment is contained in the personal view statement of the person who assesses a particular subject on each of the characteristics or attitudes listed. This assessment is stated in the form of a scale/value of 1-4. The value of 1 means very bad and on the other hand, the value of 4 means very good.

\section{Theoretical Framework}

\subsection{Evaluation}

Spaulding et al. [5] understood evaluation as an activity carried out for the purpose of making decisions which then produces recommendations for program improvement. Chelimsky, Shadish and Shadish [6] stated that policy evaluation is a determination of the results obtained from several activities designed to meet certain valuable goals or objectives. Rist [7] explains that evaluation is carried out in order to obtain the best possible results in the most efficient way possible for the community. The main criterion for evaluation is the extent to which success has been obtained after the implementation of policy programs.

\subsection{Policy Evaluation}

Policy evaluation is carried out to determine the level of performance of a policy in terms of achieving policy goals and objectives while policy efficiency is also taken into account. Policy evaluation in this case is also carried out with the aim of measuring the quality of the output or output produced. In the next stage, the evaluated policy also measures the resulting impact, both from the positive and negative sides. The input from the evaluation in this case becomes the final goal to make future policies that are in accordance with conditions in the field related to implementation and obstacles that can be minimized so that policies can run effectively and efficiently.

\subsection{Indicator-Policy Evaluation Indicator}

This research uses the e-learning theory previously conducted by Marlina [8], Riyanda et al. [9], Rahmat et al. [10], and Nirsal et al. [11] which can be concluded that in the teaching and learning process using the e-learning method, the organizational environment, aspects of human resource competence, clarity of information, and systems and services that can create a learning process must be prepared for a better teaching without them having to be face to face and can be done anywhere and at a time limit. In addition, this research also seeks to evaluate the online lecture policy using four of the five indicators put forward by Agustino [12], namely:

1. Apparatus resources (in this case lecturers). The success of a policy is very much determined by the apparatus resources. This is because through the apparatus (implementer), how far they understand what they are doing can be seen.

2. Institutional. The institutional context in this case relates to smooth coordination, flexible discretion, systems within organizations, leadership patterns and synergy between institutions which becomes indications of positive evaluation. 
3. Facilities, infrastructure and technology. This indicator can be used to assess how the provision of facilities, infrastructure and technology supports the success of policies.

4. Financial. Financial support is an important criterion for seeing or assessing a policy. This is because without financial support, a policy or program will be difficult to implement.

\section{Findings and Discussion}

\subsection{Respondents}

Respondents in this study were 636 students with the female gender as much as $66,4 \%$, while the male gender 33,6\%. The respondents mostly came from the Department of Public Administration with as many as $38,2 \%$, then followed by the Department of International Relations with $18,4 \%$. It is known that $18,2 \%$ of the respondents in the Department of Communication Science attended, while the Department of Governmental Sciences was 13,7\% and the Department of Business Administration was 11,5\%. Most respondents were from undergraduate study programs with $87,6 \%$, respondents from $\mathrm{S} 2$ study programs were $8,6 \%$ and the rest were from S3 as much as $3,8 \%$.

Respondents who took part in the research as shown in diagram 3.4 are mostly respondents from the class of 2019 , which is $50,2 \%$ or half of the existing respondents, then followed by class of 2018 respondents as many as $25,9 \%$ and class of 2017 as many as $22,3 \%$. In the 2016 class, it is known that only $1,1 \%$ attended, and in the 2015 class, only $0,5 \%$ of the total attended.

Table 1. Respondent profile

\begin{tabular}{|c|c|c|c|}
\hline Indicator & Respondents & Total & Percentage \\
\hline \multirow{3}{*}{ Gender } & Female & 422 & $66,4 \%$ \\
\cline { 2 - 4 } & Male & 213 & $33,6 \%$ \\
\hline \multirow{4}{*}{ Department } & Public Administration & 243 & $38,2 \%$ \\
\cline { 2 - 4 } & Political and Governmental Sciences & 87 & $13,7 \%$ \\
\cline { 2 - 4 } & Business Administration & 73 & $11,5 \%$ \\
\cline { 2 - 4 } & Communication Sciences & 116 & $18,2 \%$ \\
\cline { 2 - 4 } & International Relations & 117 & $18,4 \%$ \\
\hline \multirow{3}{*}{ Study } & $\mathrm{S} 1$ & 557 & $87,6 \%$ \\
\cline { 2 - 4 } & $\mathrm{S} 2$ & 55 & $8,6 \%$ \\
\cline { 2 - 4 } & $\mathrm{S} 3$ & 25 & $3,8 \%$ \\
\cline { 2 - 4 } & 2015 & 3 & $0,5 \%$ \\
\cline { 2 - 4 } Class Year & 2016 & 142 & $1,1 \%$ \\
\cline { 2 - 4 } & 2017 & 319 & $22,3 \%$ \\
\cline { 2 - 4 } & 2018 & $50,2 \%$ \\
\cline { 2 - 4 } & 2019 & & $25 \%$ \\
\hline
\end{tabular}

\subsection{Research Results}

The results of this research can be seen in table 2, where there are 4 (indicators) that are used as a reference for analyzing, namely:

a) Lecturer resources,

b) Institutional, 
c) Facilities, infrastructure, and technology, and

d) Financial.

The results of the respondent's assessment are presented with a range of values of 1-4 (one to four) in a graph, which are then grouped into 4 assessment categories, namely very good, good, good enough, and poor in a table. The following is a complete description of the evaluation of the online lecture teaching and learning process (Kulon) at FISIP Undip. The interpretation of the mean values is determined as follows:

a) The "Poor" category is if the average value is in the range of 1-1,08.

b) "Good Enough" category is when the mean is between $>1,08-2,4$.

c) "Good" category is when the mean is between $>2,4-3,2$.

d) "Very Good" category is when the mean is between $>3,2$.

\subsubsection{Lecturer Resources Indicator (SDA)}

To measure how lecturer resources (SDA) conduct the online lecture process at FISIP Undip, we can see: (1) the adaptability of lecturer resources (X1-1), (2) the ability of lecturer resources to apply technology (X2-2).

According to data X1-1, the largest percentage of the value of the adaptation process of lecturers is $49,2 \%$ good, while $17,6 \%$ of the assessment is very good. Thus, overall, $66,8 \%$ considered that the lecturers had adapted well to the online lecture learning process. However, $28,8 \%$ thought it was good enough and $4,4 \%$ of respondents thought it was poor.

The X1-2 data shows that the majority of respondents stated that the lecturers had applied the technology used for online lectures well as many as $69,9 \%$ with a distribution of $51,3 \%$ said it was good and $18,6 \%$ said it was very good, $25,9 \%$ said it was good enough and $4,2 \%$ poor.

In conclusion, Table 2 shows that the lecturer resources indicator has a mean value of 2,82 . Overall, the average value of the lecturer resources indicator is in the "good" category.

\subsubsection{Online Facilities, Infrastructure and Technology Indicator}

There are seven sub indicators of Infrastructure and Technology as follows:

a) Easiness of SSO Login (X2-1)

The largest percentage regarding the Easiness of SSO Login was 53,6\% on good enough, $21,1 \%$ of the assessment was good, $19,0 \%$ of the respondents thought it was poor, and the remaining $6,3 \%$ of respondents considered it very good. Thus, it can be concluded that the SSO Undip Login process is quite easy.

b) Easiness of Online Lecture Login (X2-2)

The largest percentage regarding the Easiness of Kulon Login at SSO shows as much as $48,9 \%$ good enough. As many as $31,9 \%$ considered it good, as many as $12,3 \%$ of thought it was poor, and the remaining $6,9 \%$ of considered it very good. Based on the assessment in diagram 3.13, it can be seen that the Kulon Login process at SSO is quite easy.

c) Easiness of MS Teams Login (X2-3)

The largest percentage regarding the Easiness of Microsoft Teams Login at SSO was $58,8 \%$ which was good enough, while $22,2 \%$ was poor. As many as $17,1 \%$ rated it as good, and the remaining 1,9\% considered it very good. Based on the assessment in Diagram 3.14, it can be seen that the Microsoft Teams Login process in SSO is quite easy.

d) Kulon application Feature Diversity (X2-4)

The largest percentage of the diversity of features of the Kulon application was 53,5\% which was good enough, while $27,4 \%$ was good. As many as $13,2 \%$ of considered it poor 
and the remaining $6 \%$ were very good. Based on the assessment in diagram 3.13 it can be seen that the diversity of Kulon Application features such as quizzes, assignments, materials, and teaching materials is good enough.

e) MS Teams application Feature Diversity (X2-5)

The largest percentage regarding the variety of features of MS Teams applications such as quizzes, assignments, materials, teaching materials were $53,9 \%$ good enough, while $28,8 \%$ were poor. As many as $15,4 \%$ rated it as good, and the remaining $1,9 \%$ was very good. Based on the assessment in diagram 3.16, it can be seen that the diversity of features of MS Teams like quizzes, assignments, materials, teaching materials are good enough.

f) Convenience of the Infrastructure and Technology used (X2-6)

The largest percentage regarding the convenience of facilities, infrastructure, and online technology used was $40,7 \%$ comfortable and $10,1 \%$ very comfortable. Meanwhile, $39,5 \%$ considered it comfortable enough, and the remaining 9,7\% less comfortable. Based on diagram 3.17, it can be seen that the convenience of the facilities, infrastructure, and online technology used is comfortable.

g) Assistance of Facilities, Infrastructure and Technology in understanding the material The largest percentage regarding the assistance of facilities, infrastructure, and online technology in understanding lectures is as much as $43,1 \%$ mediocre, and $28,8 \%$ quite helpful. Meanwhile, 17,8\% considered it very helpful, and the remaining 10,4\% considered it less helpful. It can be seen in table 2 that the average value of the indicators of online facilities, infrastructure and technology is 2,24; which means "good enough". The highest average value $(2,54)$ is the sub-indicator of online facilities, infrastructure and technology assistance in understanding the material.

Table 2. Recapitulation results of online course at FISIP Undip

\begin{tabular}{|c|c|c|c|c|c|c|c|}
\hline \multicolumn{8}{|c|}{ Recapitulation of Lecturers at FISIP Undip } \\
\hline \multirow{2}{*}{ Item } & \multirow{2}{*}{$\begin{array}{c}\text { Resp. } \\
\text { Amount }\end{array}$} & \multicolumn{4}{|c|}{ Score } & \multirow{2}{*}{$\begin{array}{l}\text { Total } \\
\text { Score }\end{array}$} & \multirow{2}{*}{ Mean } \\
\hline & & 1 & 2 & 3 & 4 & & \\
\hline \multirow{2}{*}{$\mathrm{X} 1-1$} & \multirow{2}{*}{636} & 28 & 183 & 313 & 112 & \multirow{2}{*}{1781} & \multirow{2}{*}{2,8} \\
\hline & & $(4,4 \%)$ & $(28,8 \%)$ & $(49,2 \%)$ & $(17,6 \%)$ & & \\
\hline \multirow{2}{*}{$\mathrm{X} 1-2$} & \multirow{2}{*}{636} & 27 & 165 & 326 & 11 & \multirow{2}{*}{1807} & \multirow{2}{*}{2,84} \\
\hline & & $(4,2 \%)$ & $(25,9 \%)$ & $(51,3 \%)$ & $(1,7 \%)$ & & \\
\hline \multicolumn{7}{|c|}{ Lecturer Mean Value } & 2,82 \\
\hline
\end{tabular}

\begin{tabular}{|c|c|c|c|c|c|c|c|}
\hline \multicolumn{8}{|c|}{ Recapitulation of Facilities, Infrastructure and Technology Online } \\
\hline \multirow{2}{*}{ Item } & \multirow{2}{*}{$\begin{array}{c}\text { Resp. } \\
\text { Amount }\end{array}$} & \multicolumn{4}{|c|}{ Score } & \multirow{2}{*}{$\begin{array}{l}\text { Total } \\
\text { Score }\end{array}$} & \multirow{2}{*}{ Median } \\
\hline & & 1 & 2 & 3 & 4 & & \\
\hline \multirow{2}{*}{$\mathrm{X} 2-1$} & \multirow{2}{*}{636} & 121 & 341 & 134 & 40 & \multirow{2}{*}{1365} & \multirow{2}{*}{2,15} \\
\hline & & $(19,0 \%)$ & $(53,6 \%)$ & $(21,1 \%)$ & $(6,3 \%)$ & & \\
\hline \multirow{2}{*}{$X 2-2$} & \multirow{2}{*}{636} & 78 & 311 & 203 & 44 & \multirow{2}{*}{1485} & \multirow{2}{*}{2,33} \\
\hline & & $(12,3 \%)$ & $(48,9 \%)$ & $(31,9 \%)$ & $(6,9 \%)$ & & \\
\hline \multirow{2}{*}{$\mathrm{X} 2-3$} & \multirow{2}{*}{636} & 141 & 374 & 109 & 12 & \multirow{2}{*}{1264} & \multirow{2}{*}{1,99} \\
\hline & & $(22,2 \%)$ & $(58,8 \%)$ & $(17,1 \%)$ & $(1,9 \%)$ & & \\
\hline \multirow{2}{*}{$\mathrm{X} 2-4$} & \multirow{2}{*}{636} & 84 & 340 & 174 & 38 & \multirow{2}{*}{1438} & \multirow{2}{*}{2,26} \\
\hline & & $(13,2 \%)$ & $(53,5 \%)$ & $(27,4 \%)$ & $(6,0 \%)$ & & \\
\hline \multirow{2}{*}{$X 2-5$} & \multirow{2}{*}{636} & 183 & 343 & 98 & 12 & \multirow{2}{*}{1211} & \multirow{2}{*}{1,9} \\
\hline & & $(28,8 \%)$ & $(53,9 \%)$ & $(15,4 \%)$ & $(1,9 \%)$ & & \\
\hline \multirow{2}{*}{$\mathrm{X} 2-6$} & \multirow{2}{*}{636} & 62 & 251 & 259 & 64 & \multirow{2}{*}{1597} & \multirow{2}{*}{2,51} \\
\hline & & $(9,7 \%)$ & $(39,5 \%)$ & $(40,7 \%)$ & $(10,1 \%)$ & & \\
\hline
\end{tabular}




\begin{tabular}{|c|c|c|c|c|c|c|c|}
\hline \multirow{2}{*}{ X2-7 } & \multirow{2}{*}{636} & 66 & 274 & 183 & 113 & \multirow{2}{*}{1615} & \multirow{2}{*}{2,54} \\
\cline { 3 - 5 } & & $(10,4 \%)$ & $(43,1 \%)$ & $(28,8 \%)$ & $(17,8 \%)$ & \\
\hline \multicolumn{3}{|c|}{ Vean Value of Online Facilities, Infrastructure and Technology Indicators } & 2,24 \\
\hline
\end{tabular}

\begin{tabular}{|c|c|c|c|c|c|c|c|c|c|}
\hline \multicolumn{10}{|c|}{ Recapitulation of Online Course Application Scores } \\
\hline \multirow[b]{2}{*}{ Item } & \multirow[b]{2}{*}{$\begin{array}{c}\text { Resp. } \\
\text { Amount }\end{array}$} & \multicolumn{8}{|c|}{$\begin{array}{ll} & \text { Online Application Score } \\
\end{array}$} \\
\hline & & MS Team & WA & Zoom & $\begin{array}{c}\text { Google } \\
\text { Classroom }\end{array}$ & Skype & $\begin{array}{c}\text { Kulon } \\
\text { SSO }\end{array}$ & Email & Other \\
\hline \multirow{2}{*}{ X3-1 } & \multirow{2}{*}{636} & 551 & 78 & 4 & \begin{tabular}{l|l}
3 & \\
\end{tabular} & 0 & 0 & 0 & 0 \\
\hline & & $(86,6 \%)$ & $(12,3 \%)$ & $(0,6 \%)$ & $(0,5 \%)$ & $(0,0 \%)$ & $(0,0 \%)$ & $(0,0 \%)$ & $(0,0 \%)$ \\
\hline \multirow{2}{*}{$\mathrm{X} 3-2$} & \multirow{2}{*}{636} & 534 & 21 & 64 & 7 & 0 & 6 & 1 & 3 \\
\hline & & $(84,0 \%$ & $(3,3 \%)$ & $(10,1 \%)$ & $1,1 \%)$ & $(0,0 \%)$ & $(0,9 \%)$ & $(0,2 \%)$ & $(0,5 \%)$ \\
\hline \multirow{2}{*}{$\mathrm{X} 3-3$} & \multirow{2}{*}{636} & 336 & 228 & 20 & 2 & 3 & 6 & 7 & 34 \\
\hline & & $(52,8 \%$ & $(35,8 \%)$ & $(3,1 \%)$ & $(0,3 \%)$ & $(0,5 \%)$ & $(0,9 \%)$ & $(1,1 \%)$ & $(5,3 \%)$ \\
\hline \multirow{2}{*}{$\mathrm{X} 3-4$} & \multirow{2}{*}{636} & 353 & 184 & 29 & 7 & 1 & 10 & 3 & 49 \\
\hline & & $(55,5 \%$ & $(28,9 \%)$ & $(4,6 \%)$ & $(1,1 \%)$ & $(0,2 \%)$ & $(1,6 \%)$ & $(0,5 \%)$ & $(7,7 \%)$ \\
\hline \multirow{2}{*}{ X3-5 } & \multirow{2}{*}{636} & 459 & 136 & 5 & 4 & 0 & 15 & 7 & 10 \\
\hline & & $(72,2 \%$ & $(21,4 \%)$ & $(0,8 \%)$ & $(0,6 \%)$ & $(0,0 \%)$ & $(2,4 \%)$ & $(1,1 \%)$ & $(1,6 \%)$ \\
\hline
\end{tabular}

\begin{tabular}{|c|c|c|c|c|c|c|c|}
\hline \multicolumn{8}{|c|}{ Recapitulation of Online Tuition Financial Assistance } \\
\cline { 1 - 5 } Item & Resp. & \multicolumn{3}{|c|}{ Total Score } & \multirow{2}{*}{ Median } \\
\cline { 3 - 6 } & Amount & 1 & 2 & 3 & 4 & \multirow{2}{*}{1595} & 2,5 \\
\hline \multirow{2}{*}{ X4-1 } & \multirow{2}{*}{636} & 52 & 266 & 261 & 57 & $2,0 \%$ \\
\cline { 3 - 6 } & & $8,2 \%$ & $41,8 \%$ & $41,0 \%$ & $9,0 \%$ & \\
\hline
\end{tabular}

\subsubsection{Indicators of Coordination of the Use of Online Methods in the Online Teaching and Learning Process}

Institutional indicators are indicators related to coordination in the implementation of online lectures. In this context, it is known that the implementation of online lectures makes lecturers and students use the application to bridge the implementation of online lectures. Reference in the application assessment is known from:

a) Most used Application in lectures (X3-1)

The application most often used in lectures is the MS Teams with a percentage of $86,6 \%$, WhatsApp as much as $12,3 \%, 0,6 \%$ uses Google Class Room, while as much as $0,5 \%$ uses other applications such as Zoom, Skype, Kulon SSO, etc.

b) Most comfortable Application used in lectures (X3-2)

The application that is most comfortable to use in lectures is MS Teams with a percentage of $83,8 \%$. The second application that is comfortable to use is WhatsApp as much as $10,1 \%$, while the rest are other applications from Zoom, Skype, etc.

c) Most used Application in mentoring (X3-3) (Thesis/ Seminar/ Internship/ Guardianship) MS Teams is an application often used in mentoring with a percentage of $52,8 \%$, followed by WhatsApp as much as 35,8\%. In other applications such as Zoom it is as much as 3,1\%, Email as much as $1,1 \%$, Skype as much as $0,9 \%$, Kulon SSO as much as $0,5 \%$, Google Class Room as much as 0,5 and as many as 5,3\% answered others because they have not done mentoring. 
d) Most comfortable Application in mentoring (X3-4) (Thesis/ Seminar/ Internship/ Guardianship)

MS Teams is the application most comfortable to use in mentoring with a percentage of $55,5 \%$, followed by WhatsApp which has a percentage of $28,9 \%$. Other applications such as Zoom has as much as 4,6\%, Skype as much as $1,6 \%$, Google Class Room as much as $1,1 \%$, Email as much as $0,5 \%$, Kulon SSO as much as $0,2 \%$, other applications as much as $7,7 \%$ because it has not been used for mentoring.

e) Most used Application in Examination (X3-5) (Mid-Term Exam (UTS)/ End of Term Exam (UAS)/ Thesis/ Seminar)

The application most often used in examinations is MS Team with a percentage of $72,2 \%$, followed by WhatsApp with a percentage of $21,4 \%$. Other existing applications such as Zoom has as much as $0,8 \%$, Google Class Room as much as $0,6 \%$, Email as much as $1,1 \%$, Kulon SSO as much as 2,4\%, and other applications as much as $1,6 \%$.

In table 2 , it is known that the institutional role of Ms. Teams is very widely used and the comfort aspect is also high in lectures, the mentoring process and examination. The WhatsApp application is in the second position in the most used and comfortable, while the rest is in applications such as Zoom, Skype, Google Classroom, Kulon SSO, etc. Overall, MS Teams is the most used application and it is also high on the convenience aspect.

\subsubsection{Financial Indicator}

There are 2 sub financial indicators, namely: (1) online lecture method is burdensome for students financially (X4-1); and (2) the availability of financial assistance for the online lecture process from universities.

In table 2, it can be seen that the largest percentage regarding the online lecture method is that it is burdensome for students financially. As many as $41,8 \%$ says that it is not too burdensome, while $41 \%$ says it is quite burdensome. Meanwhile, $9 \%$ of the respondents considered it very burdensome, and $8,2 \%$ not burdensome. Based on diagram 3.20, it can be seen that the online lecture method is not too burdensome for students financially. In addition, $50,5 \%$ of the respondents answered that they received assistance, while $49,5 \%$ felt that they did not receive assistance.

\section{Conclusion}

This research shows that based on the answers to the questionnaire from 636 students across class years from five departments at the Faculty of Social and Political Sciences of Undip from undergraduate, postgraduate and doctoral level, the whole online learning process has varying results. On the indicator of lecturer resources, the results of the assessments are "good", while on the Indicators of Online Facilities, Infrastructure and Technology, the results are "good enough". On the indicators of coordinating the use of online methods in the online teaching and learning process, MS Teams is still a popular learning tool for lecturers. Finally, on the financial indicators, half of the respondents answered that they had received financial assistance, and online lectures were considered to be not too burdensome. 


\section{References}

[1] A. Ratnasari, "Studi Pengaruh Penerapan E-learning Terhadap Keaktifan Mahasiswa dalam Kegiatan Belajar Mengajar Studi Kasus Universitas Mercu Buana Jakarta," in Seminar Nasional Aplikasi Teknologi Informasi (SNATI), 2012.

[2] S. Ente, "Evaluasi pemahaman penggunaan web e-learning berbasis moodle menggunakan metode colles (studi kasus: sekolah menengah atas negeri 100 jakarta)." Universitas Multimeida Nusantara, 2015.

[3] Y. Budiarti, "Penerapan Knowledge Management System Pada E-Learning Dengan Metode COLLES Untuk Meningkatkan Hasil Belajar Siswa," Indones. J. Softw. Eng., vol. 1, no. 1, pp. 36-41, 2015.

[4] P. D. Sugiyono, "Statistika untuk penelitian," Bandung CV. Alf., 2006.

[5] S. A. Spaulding, R. H. Horner, S. L. May, and C. G. Vincent, "Evaluation brief: Implementation of school-wide PBS across the United States," Washington, DC Off. Spec. Educ. Programs Tech. Assist. Cent. Posit. Behav. Interv. Support. Retrieved June, vol. 26, p. 2009, 2008.

[6] E. Chelimsky, W. R. Shadish, and J. W. R. Shadish, Evaluation for the 21st century: A handbook. Sage, 1997.

[7] R. C. Rist, Policy Evaluation. Cambridge: Cambridge Press, 1995.

[8] D. Marlina, "Evaluasi Penerapan e-Learning Fakultas Psikologi UIR Menggunakan Metode Hot Fit.” Universitas Islam Negeri Sultan Syarif Kasim Riau, 2019.

[9] A. R. Riyanda, K. Herlina, and B. A. Wicaksono, "Evaluasi Implementasi Sistem Pembelajaran Daring Fakultas Keguruan Dan Ilmu Pendidikan Universitas Lampung," IKRA-ITH Hum. J. Sos. Dan Hum., vol. 4, no. 1, pp. 66-71, 2020.

[10] A. B. D. Rahmat, K. B. Seminar, and A. I. Suroso, "Evaluasi Keberhasilan E-Learning Dalam Perspektif Sistem Informasi (Studi Kasus Universitas Terbuka)," J. Apl. Bisnis dan Manaj., vol. 5, no. 3, p. 373, 2019.

[11] N. Nirsal, S. Suhardi, and F. N. Yasir, "Analisis dan Evaluasi Pemanfaatan Sistem E-Learning Pada Fakultas Teknik Komputer Universitas Cokroaminoto Palopo," d'ComPutarE J. Ilm. Inf. Technol., vol. 9, no. 1, pp. 1-7, 2019.

[12] L. Agustino, "Dasar-dasar kebijakan publik (Edisi Revisi)," Alf. Bandung, 2016. 